\title{
The Etiology, Mechanisms, and Treatment of Churg-Strauss Syndrome
}

\author{
Tsurikisawa N., Saito H., Oshikata C., Tsuburai T. and Akiyama K. \\ Clinical Research Center for Allergy and Rheumatology, National Hospital Organization \\ Sagamihara National Hospital, \\ Japan
}

\section{Introduction}

Churg-Strauss syndrome (CSS) is a rare disease characterized by allergic granulomatosis and necrotizing vasculitis following peripheral blood eosinophilia and eosinophilic tissue infiltration (Churg \& Strauss, 1951). CSS is classified as a vasculitis of small and mediumsized arteries (Jennette \& Falk, 1995), although the vasculitis is not often apparent in the initial phases of the disease. It occurs mainly in adults, almost always in patients with a history of bronchial asthma, and is associated with chronic rhinosinusitis. The most frequently affected organs are the lungs and the ear, nose, and throat (ENT) system, followed by the skin. Involvement of the cardiac and gastrointestinal tract systems determines the prognosis. Nonspecific immunosuppressive therapy with corticosteroids (CSs), cyclophosphamide (CYC) and other drugs produces good responses initially in most patients, but relapses are frequent, especially in the early disease phase, and morbidity and mortality remain important problems. Our research has explored the etiology of CSS by use of HLA analysis and has shown that the clinical and immunological manifestations of asthma occur in the pre-vasculitic phase of the disease. Our work further indicates that treatment, especially in the form of intravenous immunoglobulin (IVIG), is beneficial.

\section{Clinical manifestations, mechanisms, and treatment}

\subsection{Etiology and genetic factors}

The precise etiologies of CSS and the role played by genetic factors remain unknown. In some CSS patients, vasculitis is apparent within a few weeks or months of exposure to putative triggers, such as rapid discontinuation of oral corticosteroids, vaccination, desensitization, viral infection, or medication with leukotriene receptor antagonists. Although there are some reports of genetic factors, such as the IL10.2 haplotype (Vaglio et al., 2007) and HLA (human leukocyte antigen)-DPB1 (Wieczorek et al., 2008), influencing susceptibility to CSS, to date there is no compelling evidence supporting the involvement of such factors. Familial cases of systemic vasculitis associated with p-ANCA (p-antineutrophil cytoplasmic antibody)-positive vasculitis or Wegener's granulomatosis (WG) have been reported, but there have been no reports of familial CSS, excluding cases of familial vasculitis with CSS and WG in two first-degree relatives. We presented the first case of familial CSS in two sisters with atopic-type bronchial asthma and negativity for p-ANCA 
(Tsurikisawa et al., 2007). The two sisters had seven siblings, for a total of four females and five males. Eight were still alive, but both parents were dead. The parents had no known history of atopy, and of the siblings only another sister, the oldest, also had bronchial asthma and atopy. We analyzed human leukocyte antigen (HLA)-A, HLA-B, HLA-DRB1, HLA-DQA1, HLA-DQB1, and HLA-DPB1 in the two CSS sisters and their six living siblings (Table 1). All four sisters, including the two CSS sisters, had HLA-A02, HLA-B48, DRB1-15, DQA1-01, DQB1-06, and DPB1-20; all four brothers had HLA-A20, HLA-B39, DRB1-04, DQA1-03, DQB1-03, and DPB1-04. Testing revealed no significant differences in the frequencies of any of the HLAs $(P=0.102-0.67)$. Our results and accumulated clinical evidence indicate that CSS is not a heritable disease.

\begin{tabular}{|l|ll|ll|ll|ll|ll|ll|}
\hline & \multicolumn{2}{|l}{ HLA-A } & \multicolumn{2}{l}{ HLA-B } & \multicolumn{2}{l|}{ DRB1 } & DQA1 & DQB1 & DPB1 \\
\hline Patient 1 & 02 & 24 & 48 & 52 & 15 & 15 & 01 & 01 & 06 & 06 & 20 & 09 \\
Patient 2 & 02 & 02 & 48 & 40 & 15 & 09 & 01 & 03 & 06 & 03 & 20 & 05 \\
Sister 1 & 02 & 24 & 48 & 52 & 15 & 15 & 01 & 01 & 06 & 06 & 20 & 09 \\
Sister 2 & 02 & 02 & 48 & 40 & 15 & 90 & 01 & 03 & 06 & 30 & 20 & 05 \\
Brother 1 & 20 & 24 & 39 & 52 & 15 & 04 & 01 & 03 & 06 & 03 & 05 & 09 \\
Brother 2 & 20 & 24 & 39 & 52 & 15 & 04 & 01 & 03 & 06 & 03 & 05 & 09 \\
Brother 3 & 20 & 02 & 39 & 40 & 90 & 04 & 03 & 03 & 30 & 03 & 05 & 05 \\
Brother 4 & 20 & 24 & 39 & 52 & 15 & 04 & 01 & 03 & 06 & 03 & 05 & 09 \\
\hline
\end{tabular}

Table 1. HLA typing of two CSS patients and their siblings.

\subsection{Clinical manifestation of vasculitis}

CSS is a rare disorder characterized by an incidence of 0.11 to 2.66 new cases per million population per year and an overall prevalence of 10.7 to 14 per 1,000,000 adults (Gatenby, 2009; Mahr, 2004; Mohammad 2007). The male-to-female ratio ranges from 0.3 to 2.3 and the mean age at onset reported in the literature varies from 38 to 52 years (range 7-74 years) (Kahn 2008; Sinico \& Bottero, 2009). Nonetheless, there is a generally agreed-upon clinical description of the disease. The frequencies of organ involvement and other clinical features of CSS previously reported by others and observed at our hospital are summarized in Table 2. CSS has been traditionally induced in ANCA-associated vasculitis, WG, and microscopic polyangiitis (MPA). The prevalence of ANCAs in CSS is less consistent than in WG or MPA, being reported in approximately $40 \%$ of cases (Guillevin et al., 1999; Kahn et al., 2008; Pagnoux \& Guillevin, 2010; Sinico \& Bottero, 2009). Recently, it was shown that different clinical phenotypes could be observed according to the presence or absence of ANCA, thereby suggesting that there are varying disease mechanisms in the pathogenesis of CSS. Increased prevalence of central nervous system involvement (Keogh \& Speck, 2003), renal involvement, peripheral neuropathy, and pulmonary hemorrhage (Sinco et al., 2005) has been reported among ANCA-positive patients. Negative ANCA status is associated with heart disease and lung involvement (Sinco et al., 2005). From these findings, it has been hypothesized that, as in WG and MPA, ANCAs may contribute directly to the endothelial 
vasculitic damage seen in ANCA-positive patients, whereas in ANCA-negative patients eosinophils may be directly responsible for the release of cationic proteins and eosinophilderived neurotoxin (Kallenberg, 2005). These data suggest that CSS, when presenting as a form of necrotizing small-vessel vasculitis, is a true ANCA-associated disease, characterized by positivity for myeloperoxidase (MPO)-ANCAs. Alternatively, ANCA-negative patients may be clinically characterized by tissue infiltration by eosinophils that results in fibrotic organ damage; their disease may belong more to the spectrum of hypereosinophilic syndromes rather than to the spectrum of ANCA vasculitis. The existence of two clinical phenotypes may reveal different pathways of pathogenicity in CSS.

\begin{tabular}{|c|c|c|c|c|c|c|}
\hline & Churg & Chumbley & Lanham & Hashimoto & Guillevin & $\begin{array}{l}\text { Our } \\
\text { cases }\end{array}$ \\
\hline & USA & USA & UK & Japan & France & Japan \\
\hline & 1951 & 1977 & 1984 & 1994 & 1999 & 2011 \\
\hline Cases & 13 & 30 & 138 & 87 & 96 & 86 \\
\hline $\mathrm{M} / \mathrm{F}$ & $4 / 9$ & $21 / 9$ & $72 / 66$ & $41 / 46$ & $45 / 51$ & $27 / 59$ \\
\hline Age mean & 33 & 47 & 38 & 47 & 48 & 53.4 \\
\hline Age range & $(7-62)$ & $(15-69)$ & & $(17-79)$ & $(17-74)$ & $(19-83)$ \\
\hline \multicolumn{7}{|c|}{ Clinical manifestations(\%) } \\
\hline Asthma & 100 & 100 & 100 & 93 & 100 & 100 \\
\hline $\begin{array}{l}\text { Pulmonary } \\
\text { infiltrates }\end{array}$ & 39 & 27 & 74 & 33 & 38 & 80 \\
\hline Nose, ear, throat & 77 & 70 & 69 & & 48 & 91 \\
\hline $\begin{array}{l}\text { Multiplex } \\
\text { mononeuritis }\end{array}$ & 69 & 63 & 64 & 65 & 78 & 99 \\
\hline Gastrointestinal & 92 & 17 & 62 & 19 & 33 & 85 \\
\hline Heart & 54 & 16 & 52 & 33 & 30 & 74 \\
\hline Arthritis & 31 & 20 & 46 & 52 & 41 & 42 \\
\hline Myalgias & & & 33 & 51 & 54 & 25 \\
\hline Skin & & 66 & 51 & & & \\
\hline Purpura & 62 & & 46 & 44 & 31 & 67 \\
\hline Nodules & 54 & 27 & 33 & 27 & 19 & 6 \\
\hline Renal & 31 & 20 & 46 & 46 & 16 & 58 \\
\hline $\begin{array}{l}\text { Central nervous } \\
\text { system }\end{array}$ & 61 & & 27 & & 8 & 18 \\
\hline
\end{tabular}

Table 2. Clinical manifestation of vasculitis 


\subsection{Mechanisms and clinical manifestations of the pre-vasculitic phase of CSS as an asthmatic phase}

Asthma is present in $96 \%$ to $100 \%$ of CSS patients and is the cardinal feature of CSS. Asthma may precede systemic vasculitis by approximately 8 years and, in some cases, by more than 30 years (Chumbley et al., 1977; Churg \& Strauss, 1951; Guillevin et al., 1999; Lhote \& Guillevin, 1995). The precise etiology of CSS and the asthmatic phase that precedes it, as well as the role of genetic factors, remains unknown. We demonstrated in a retrospective cohort study that the clinical manifestations of asthma occur in the pre-vasculitic phase of the disease (Tsurikisawa et al., 2007). The asthma of $87.5 \%$ of 24 patients in the pre-vasculitic phase of CSS at their first hospital visit was severe. It was characterized in $42.9 \%$ of these patients by a need for treatment with systemic steroids and mechanical ventilation and by the presence of sinusitis in $57.1 \%$ during the period from the first hospital visit to the onset of CSS $(P<0.0001)$ (Table 3$)$.

\begin{tabular}{cccc} 
Characteristic & $\begin{array}{c}\text { Non-CSS severe } \\
\text { asthma } \\
\mathrm{N}=130(44.2 \%)\end{array}$ & $\begin{array}{c}\text { Severe asthma } \\
\text { pre-CSS } \\
\mathrm{N}=21(87.5 \%)\end{array}$ & P-value \\
\hline $\begin{array}{c}\text { Systemic corticosteroid } \\
\text { treatment }\end{array}$ & $\mathrm{N}=9(6.9 \%)$ & $\mathrm{N}=9(42.9 \%)$ & $<0.0001$ \\
$\begin{array}{c}\text { Corticosteroid dose (in } \\
\text { mg, converted to the } \\
\text { prednisolone equivalent) } \\
\text { Inhaled corticosteroid } \\
\text { dose (in } \mu \text { g, converted to } \\
\text { the beclomethasone } \\
\text { equivalent) } \\
\begin{array}{c}\text { Intubation } \\
\text { Sinusitis }\end{array}\end{array}$ & $5.3 \pm 2.0$ & $7.2 \pm 3.6$ & $\mathrm{~N} . \mathrm{S}$ \\
& $\mathrm{N}=2(1.5 \%)$ & $\mathrm{N}=3(14.3 \%)$ & $\mathrm{N} . \mathrm{S}$ \\
& $\mathrm{N}=40(30.8 \%)$ & $\mathrm{N}=12(57.1 \%)$ & $<0.0018$ \\
\end{tabular}

Table 3. Differences between non-CSS (Churg-Strauss syndrome) severe asthma and severe asthma in the pre-vasculitic phase of CSS.

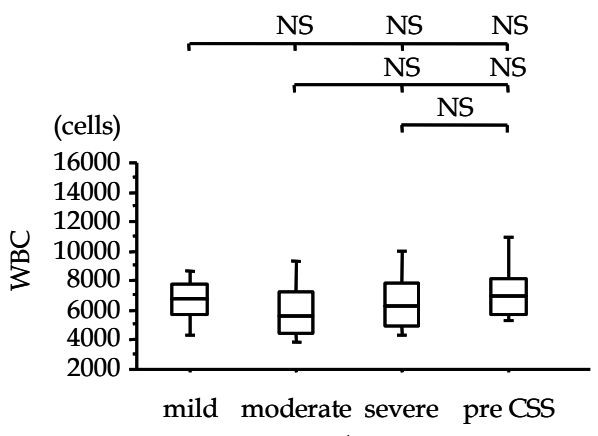

A

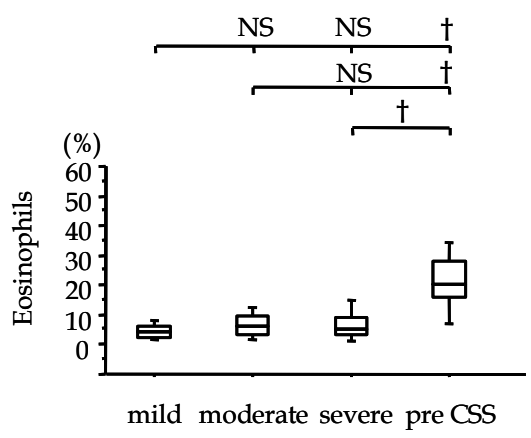

B

Fig. 1. Total numbers of white blood cells (WBC) (A)s and percentages of eosinophils (B) in the peripheral blood of all patients at the first hospital visit. The percentage of eosinophils in the peripheral blood of pre-CSS asthma patients was significantly higher than that in other asthma patients. $\dagger P<0.01$. NS: not significant. 
The percentage of eosinophils in the peripheral blood of pre-CSS asthmatics at the first hospital visit was also significantly higher than that in non-CSS asthmatics $(\mathrm{P}<0.01)$ (Fig. 1).Receiver operating characteristic (ROC) analysis was used to evaluate the diagnostic value of the percentage of eosinophils in the peripheral blood for predicting future onset of CSS. The area under the curve was $0.8992(95 \% \mathrm{CI}=0.825-0.973)$. A reasonably high specificity $(99.4 \%)$ and a high sensitivity (66.7\%), with a cut-off point of $20 \%$, were obtained (Fig. 2).

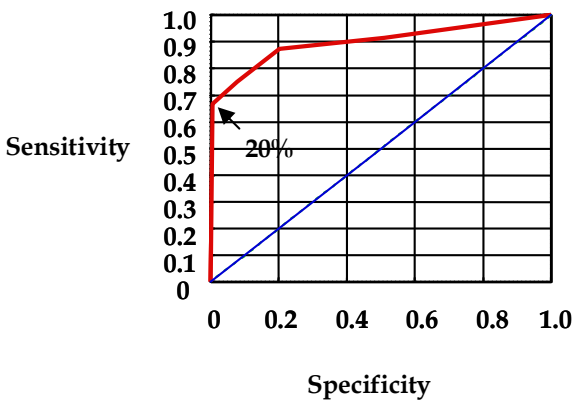

Fig. 2. ROC curve for evaluating the value of the percentage of eosinophils in the peripheral blood as a predictor of future onset of CSS

The percentage forced expiratory volume (\%FEV1) in the severe asthmatics and the asthmatic patients who later developed CSS was lower than that in patients with mild or moderate asthma $(\mathrm{p}<0.01)$. The \%FEV1 in the asthmatic patients who later developed CSS was the same as that in patients with severe asthma (Fig. 3). However, bronchial hyperresponsiveness (BHR) to acetylcholine (ACh) in the pre-vasculitic patients was significantly less severe than that in the non-CSS patients with severe asthma $(\mathrm{P}<0.01)$ and was as mild as that in patients with mild asthma (Fig. 4). Thus, asthma severity in the prevasculitic phase of CSS is related to airflow limitation and to eosinophilic inflammation in the peripheral blood, but not to BHR, which may occur as a result of airway vasculitis. We propose that asthma patients who develop CSS differ from other asthma patients, from whom they can be differentiated at the first hospital visit by evaluating these factors.

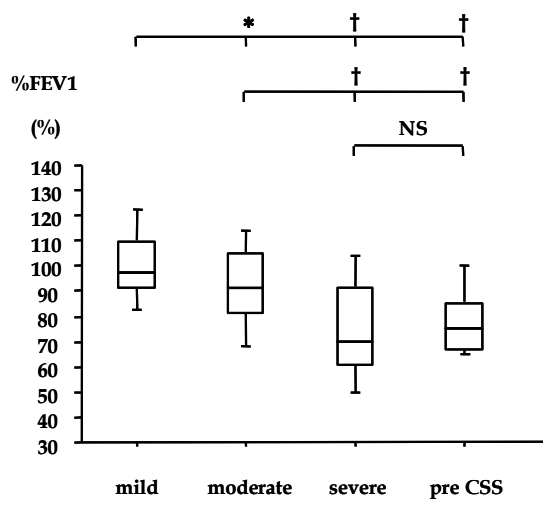

Fig. 3. FEV1 (\% predicted) at the first hospital visit in all patients. 
The \%FEV1 was measured at the first hospital visit in asthmatic patients (mild, moderate, severe) and in those who later developed CSS. The \%FEV1 in the severe asthmatics and the asthmatic patients who later developed CSS was lower than in patients with mild asthma ( $P$ $<0.01)$. However, the \%FEV1 in the asthmatic patients who later developed CSS was the same as that in patients with severe asthma. $\uparrow P<0.01$. ${ }^{*} P<0.05$. NS: not significant.

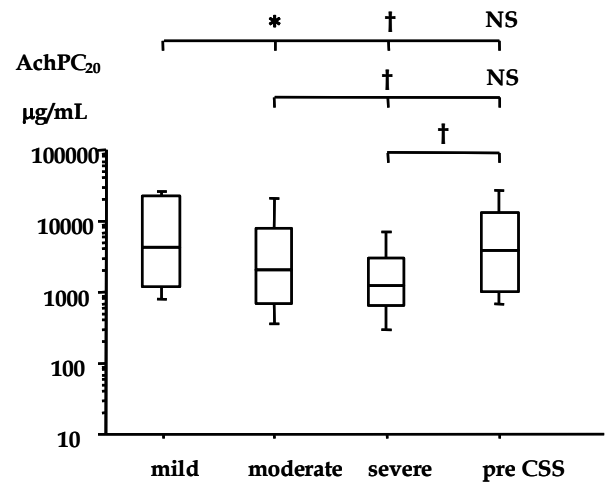

Fig. 4. Bronchial hyperresponsiveness (BHR) to inhaled Ach in all patients within 1 month of the first hospital visit.

Modified box plots represent the distribution of BHR to inhaled Ach in asthmatic patients (mild, moderate, severe) and pre-CSS asthma patients within 1 month of the first hospital visit. † Mann-Whitney Test, $P<0.01$. NS: not significant.

Eosinophilic infiltrations, such as those found in chronic eosinophilic pneumonia (CEP) and eosinophilic gastroenteritis, precede systemic vasculitis in half of all patients with CSS (Lhote \& Guillevin, 1995; Steinfeld et al., 1994). Some clinicians suggest that patients with CEP following asthma are more likely to develop CSS if the CEP is left untreated (Churg, 2001). However, some patients in whom asthma is complicated by CEP do not develop CSS. There is no clear mechanism that explains why some CEP patients with asthma develop CSS, whereas others do not. The etiology of idiopathic CEP is not understood, although in some cases CEP is caused by infection with a parasite, virus, or fungus or by drugs, toxic agents, or radiation therapy (Cottin \& Cordier, 2005; Marchand \& Cordier, 2006). Asthma occurs before CEP in about half to two-thirds of CEP patients (Cottin \& Cordier, 2005; Marchand \& Cordier 2006). Increasing numbers of eosinophils and lymphocytes in the peripheral blood and bronchoalveolar lavage fluid (BALF) contribute to the development of CEP. There are many mediators of eosinophilia in CEP, including regulated upon activation normal T-cell-expressed and -secreted (RANTES), eotaxin, thymus- and activation-regulated chemokine (TARC/CCL17), and cytokines, including IL-2, IL-3, IL-5, IL-10, IL-13, and IL-18. The number of $\mathrm{CD} 4{ }^{+} \mathrm{CD} 25^{+} \mathrm{T}$ cells in the BALF and peripheral blood is increased in patients with CEP (Albera, 1995). By contrast, peripheral blood mononuclear cells in patients with CSS secrete not only the type 1 cytokine IFN- $\gamma$, but also type 2 cytokines, such as IL-4, IL-13, and, in particular, IL-5.

T-regulatory $\left(\mathrm{T}_{\text {reg }}\right)$ cells play essential roles in maintaining immunologic homeostasis, preventing autoimmunity, and providing peripheral tolerance to antigens, including autoantigens and allergens. $\mathrm{T}_{\text {reg }}$ cells, including Tr1 (T-regulatory cells type 1 ), $\mathrm{CD}^{+} \mathrm{CD} 25^{+}$, Th3, and natural killer (NK) T cells, all suppress effector T cells of either the Th1 or Th2 
phenotype, which are involved in mediating inflammation (Jonuleit et al., 2002; Sakaguchi, 2000; Weiner, 2001). CD4+CD25+ cells are naturally occurring T-regulatory $\left(\mathrm{nT}_{\text {reg }}\right.$ ) cells that are defined as CD25 hi CD127low FOXP3+ (Roncarolo \& Battaglia, 2007). $\mathrm{nT}_{\text {reg }}$ cells mediate their suppressive effects through cell contact. Tr1 cells are antigen-specific populations derived from conventional $\mathrm{CD} 4^{+} \mathrm{CD} 25^{-}$naïve precursors following exposure to antigen under conditions of limiting costimulation, such as with IL-10, immature dendritic cells, or dexamethasone. The mechanism by which Tr1 cells exert suppression appears to be mediated by secretion of suppressor cytokines, such as IL-10 and TGF- $\beta$. Recent studies have focused on the role of $\mathrm{T}_{\text {reg }}$ cells in human diseases such as systemic lupus erythematosus, rheumatoid arthritis, cancer, Guillain-Barré syndrome, multiple sclerosis, infection, and asthma. However, whether $\mathrm{T}_{\text {reg }}$ cell activity is involved in the mechanism and etiology of CSS is not known. We examined the phenotypes and functions of CD4 ${ }^{+} \mathrm{CD} 25^{+} \mathrm{T}$ cells from asthma patients with CEP and from CSS patients at disease onset and after therapy, and we compared our findings with those in patients with general asthma. We found that, at disease onset, CSS patients, unlike CEP patients, had significantly fewer $\mathrm{CD} 4{ }^{+} \mathrm{CD} 25^{+} \mathrm{T}$ cells than patients with any type of asthma (steps 1-4) (Saito et al., 2008;

\begin{tabular}{|c|c|c|c|c|c|c|c|}
\hline & \multirow{2}{*}{$\begin{array}{c}\text { Normal } \\
\text { controls } \\
(\mathrm{n}=9)\end{array}$} & \multicolumn{4}{|c|}{ Bronchial asthma } & \multirow{2}{*}{$\begin{array}{l}\text { CSS at } \\
\text { onset }\end{array}$} & \multirow{2}{*}{$\begin{array}{c}\text { CEP at } \\
\text { onset }\end{array}$} \\
\hline & & Step 1 & Step 2 & Step 3 & Step 4 & & \\
\hline $\begin{array}{l}\text { Blood } \\
\text { eosinophils } \\
\text { (no. of cells) }\end{array}$ & $\begin{array}{c}161.9 \pm \\
65.0\end{array}$ & $\begin{array}{c}209.4 \pm \\
168.3\end{array}$ & $\begin{array}{c}290.6 \pm \\
209.8\end{array}$ & $\begin{array}{c}357.3 \pm \\
215.5\end{array}$ & $\begin{array}{c}380.0 \pm \\
517.0\end{array}$ & $\begin{array}{c}8042.6 \pm \\
6559.3^{+\&+\dagger}\end{array}$ & $\begin{array}{l}3762.6 \pm \\
2310.3 \dagger\end{array}$ \\
\hline $\mathrm{CD} 4+\mathrm{CD} 25^{+}(\%)$ & $\begin{array}{l}31.4 \pm \\
8.2 \ddagger\end{array}$ & $\begin{array}{c}52.2 \pm \\
12.2\end{array}$ & $\begin{array}{c}52.6 \pm \\
11.8\end{array}$ & $\begin{array}{c}46.2 \pm \\
6.6\end{array}$ & $\begin{array}{l}42.7 \pm \\
10.3^{*}\end{array}$ & $\begin{array}{c}34.9 \pm \\
15.6^{+\&+\dagger}\end{array}$ & $\begin{array}{c}48.1 \pm \\
11.6\end{array}$ \\
\hline IL-5 in & $0.0 \pm$ & $4.4 \pm$ & $5.2 \pm$ & $6.2 \pm$ & $4.1 \pm$ & $14.6 \pm$ & $11.2 \pm$ \\
\hline $\mathrm{CD} 4{ }^{+} \mathrm{CD} 25^{+}(\%)$ & 0.0 & 6.6 & 10.1 & 10.8 & 7.4 & $11.9+t t$ & $12.5^{t t t t}$ \\
\hline IL-10 in & $0.0 \pm$ & $4.7 \pm$ & $4.9 \pm$ & $1.1 \pm$ & $2.7 \pm$ & $0.3 \pm$ & $20.9 \pm$ \\
\hline $\mathrm{CD}^{+}{ }^{+} \mathrm{CD} 25^{+}(\%)$ & 0.0 & 7.5 & 6.3 & 2.2 & 4.4 & $1.0^{* *}$ & $17.0 \dagger \&+\dagger$ \\
\hline IL-10 in & $0.5 \pm$ & $0.5 \pm$ & $0.4 \pm$ & $0.2 \pm$ & $0.3 \pm$ & $0.1 \pm$ & $6.6 \pm$ \\
\hline $\mathrm{CD}^{+}{ }^{+} \mathrm{CD} 25^{-}(\%)$ & 1.2 & 1.5 & 0.6 & 0.5 & 0.5 & 0.1 & $11.4^{\dagger \&+\dagger}$ \\
\hline TGF- $\beta$ in & $0.0 \pm$ & $6.7 \pm$ & $4.4 \pm$ & $2.8 \pm$ & $2.6 \pm$ & $1.0 \pm$ & $6.7 \pm$ \\
\hline $\mathrm{CD} 4+{ }^{+} \mathrm{CD} 25^{+}(\%)$ & $0.0 \ddagger \ddagger$ & 10.0 & 6.9 & 5.0 & 5.9 & 0.9 ‡łł & $10.5^{\dagger t}$ \\
\hline IL-2 in & $26.3 \pm$ & $35.1 \pm$ & $32.4 \pm$ & $23.1 \pm$ & $17.0 \pm$ & $7.6 \pm$ & $22.0 \pm$ \\
\hline $\mathrm{CD} 4+\mathrm{CD} 25-(\%)$ & 25.8 & 17.9 & 22.3 & 21.2 & $16.5^{* * *}$ & $7.2 \ddagger \ddagger \ddagger$ & $17.0+t$ \\
\hline
\end{tabular}

Table 4. Eosinophil counts and cytokines in CD25+ or CD25- CD4+ T cells in normal controls, patients with asthma (as classified by the US National Institutes of Health and National Asthma Education and Prevention Program), patients with chronic eosinophilic pneumonia (CEP), and patients with Churg-Strauss syndrome (CSS)

† CSS or CEP vs. control and Step 1 and Step 2 and Step 3 and Step 4: $P<0.01$; † CSS vs. CEP: $P<0.01$; t†† CSS vs. control and Step 1 and Step 2 and Step 4: $P<0.01$, vs. Step 3: $P<0.05$; ††t† CEP vs. control: $P<0.01$, vs. Step 1 and Step 2 and Step 4: $P<0.05$; ${ }^{*}$ Step 4 vs. Step 1 and Step 2: $P<0.01$; ${ }^{* *}$ : CSS vs. Step 1 and Step 2: $P<0.05$;

*** Step 4 vs. Step 1: $P<0.01$, vs. Step 2: $P<0.05$; $\ddagger$ control vs. Step 1 and Step 2 and Step 3 and CEP: $P<$ 0.01 , vs. Step 4: $P<0.05$; $¥$ control vs. Step 1 and Step 2 and Step 3 and Step 4 and CEP: $P<0.01$; $¥ \ddagger$ CSS vs. Step 1 and Step 2: $P<0.01$ 
Tsurikisawa et al., 2008)(Table 4). CD4 ${ }^{+} \mathrm{CD} 25^{+} \mathrm{T}$ cells producing IL-10 were rarely detected in CSS patients at disease onset or relapse, whereas the numbers of IL-10-producing T cells in CEP patients were high at disease onset. Fewer CD4 ${ }^{+} \mathrm{CD} 25^{-} \mathrm{T}$ cells producing IL-2 were found in CSS patients before treatment than were found in CEP patients at disease onset $(P$ $<0.01$ ) (Table 4). The proportions of $\mathrm{CD}^{+}{ }^{+} \mathrm{CD} 25^{+} \mathrm{T}$ cells producing IL-10 and of CD4 ${ }^{+} \mathrm{CD} 25^{-}$ T cells producing IL-2 in CSS patients significantly increased at remission after treatment $(P$ $<0.01$ ) (Fig 5). We confirmed that maintenance of the numbers of $\mathrm{T}_{\text {reg }}$ cells in asthma patients with CEP may inhibit CSS development via the action of cytokines, such as IL-10 and IL-2, produced by $\mathrm{CD} 4{ }^{+} \mathrm{CD} 25^{+}$and $\mathrm{CD} 4{ }^{+} \mathrm{CD} 25^{-} \mathrm{T}$ cells, respectively.

In contrast, the $\mathrm{CD} 4{ }^{+} \mathrm{CD} 25^{+} \mathrm{T}$ cell count in patients with $\mathrm{CEP}$ at onset was the same as that in asthmatics at every step of asthma (Table 4) and did not change even with improvement of the disease (Fig. 5). The $\mathrm{CD} 4{ }^{+} \mathrm{CD} 25^{+} \mathrm{T}$ cell count in patients with CSS significantly increased with either relapse or remission after treatment, and this increase was significantly greater in patients in remission than in those who relapsed $(P<0.01)$ (Fig. 5). Moreover, when we compared the intracellular cytokine levels of IL-10 and TGF- $\beta$ with the serum levels of IL-10 (all patients assayed: $<2.0 \mathrm{pg} / \mathrm{mL}$ ) and TGF- $\beta$ (all patients assayed: $<8.0$ $\mathrm{pg} / \mathrm{mL}$ ), we found that the serum IL-10 levels were extremely low in all patients with asthma, CSS, and CEP. There was not significant the serum IL-10 level among three groups. It is not clear why there were no significant differences among the serum levels of these cytokines yet there were significant differences among the intracellular levels.

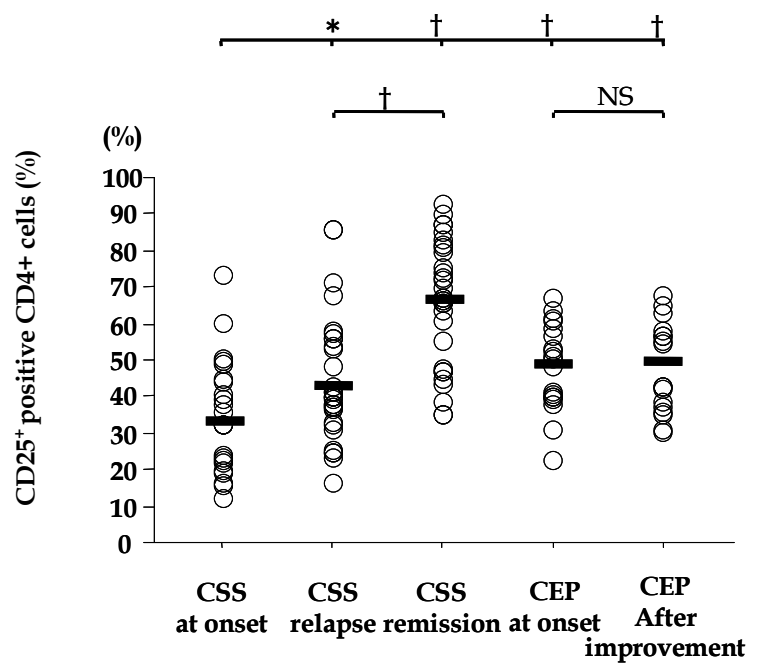

Fig. 5. Percentages of CD4+ among CD25+ $\mathrm{T}$ cells in patients with CSS and CEP at disease onset and after treatment. Median values are shown by horizontal bars. Differences between patient groups were evaluated by using the Mann-Whitney $U$ test. $\dagger P<0.01$. ${ }^{*} P<0.05$. NS: not significant.

The number of $\mathrm{CD} 4{ }^{+} \mathrm{CD} 25^{+} \mathrm{T}$ cells producing IL-5, which causes eosinophilia in peripheral blood cells and lung tissue, was high in CSS and CEP patients at disease onset and decreased significantly after treatment of CSS and improvement of CEP (Fig. 6a). 
$\mathrm{CD} 4{ }^{+} \mathrm{CD} 25^{+} \mathrm{T}$ cells producing IL-10 were rarely detected in patients with CSS at onset or in those who relapsed. However, when patients with CSS achieved clinical remission after treatment, the number of $\mathrm{CD} 4{ }^{+} \mathrm{CD} 25^{+} \mathrm{T}$ cells producing IL-10 significantly increased compared with the number at onset. The number of $\mathrm{CD} 4{ }^{+} \mathrm{CD} 25^{+} \mathrm{T}$ cells producing IL-10 in patients with CEP was high at disease onset and decreased significantly after improvement of eosinophilic pneumonia (Fig. 6(b)). The number of CD4+CD25- T cells producing IL-2 in patients with CSS at onset was significantly less than that in patients with CEP at onset.

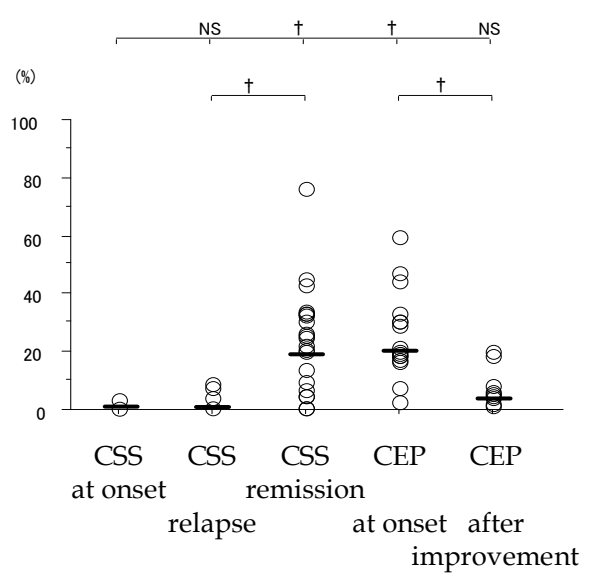

(a) IL-5 in $\mathrm{CD} 4{ }^{+} \mathrm{CD} 25$

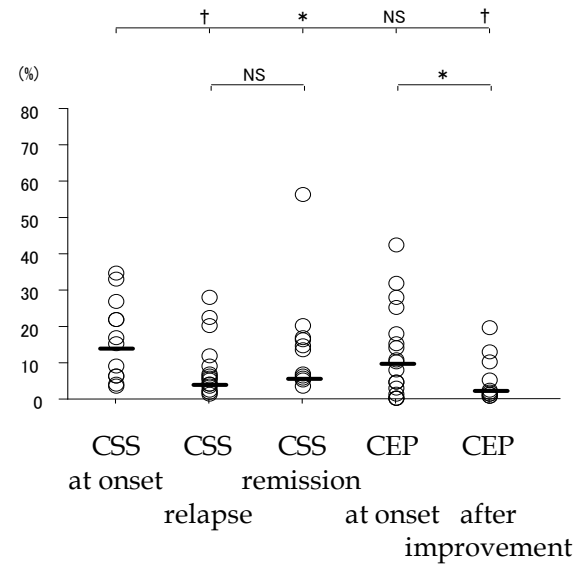

(b) IL-10 in CD4+CD25+

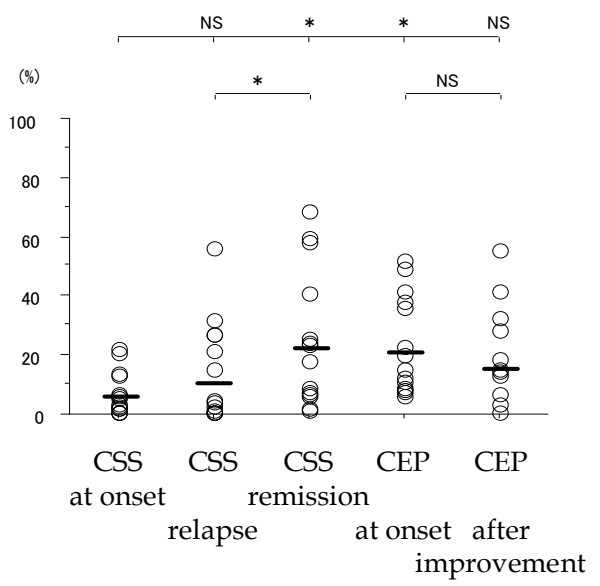

(c) IL-2 in CD4+CD25-

Fig. 6. (a) Percentages of CD4 ${ }^{+} \mathrm{CD} 25^{+} \mathrm{T}$ cells producing IL-5; (b) $\mathrm{CD} 4{ }^{+} \mathrm{CD} 25^{+} \mathrm{T}$ cells producing IL-10; and (c) CD4 ${ }^{+} \mathrm{CD} 25^{-} \mathrm{T}$ cells producing IL-2 in patients with CSS or CEP at disease onset and after treatment. Median values are shown by horizontal bars. Differences between patient groups were evaluated by using the Mann-Whitney $U$ test. $† P<0.01$. ${ }^{*} P<$ 0.05. NS: not significant. 
After treatment, CSS patients who achieved remission showed a significant increase in the number of $\mathrm{CD} 4{ }^{+} \mathrm{CD} 25-\mathrm{T}$ cells producing IL-2, to the level seen in CEP patients at disease onset, but there was no change in the count of $\mathrm{CD} 4{ }^{+} \mathrm{CD} 25^{-} \mathrm{T}$ cells producing IL-2 in patients with CEP between disease onset and improvement (Fig. 6c). The number of organs involved was significantly negatively correlated with the percentage of $\mathrm{CD} 4{ }^{+} \mathrm{CD} 25^{+} \mathrm{T}$ cells at onset, remission, and relapse in CSS patients $(r=-0.51, P<0.01$, Fig. 7). The percentage of CD25+ $\mathrm{CD}^{+} \mathrm{T}$ cells was correlated with IL-10 production in all patients with stable asthma and in those with CSS or CEP at onset $(R=0.42, P<0.01$; data not shown). These results show that the $\mathrm{CD} 4{ }^{+} \mathrm{CD} 25^{+} \mathrm{T}$ cells producing IL-10 were Tr1 cells.

Dysregulated production of IL-17 is associated with human autoimmune diseases, including multiple sclerosis, inflammatory bowel disease, and psoriasis. $\mathrm{CD}^{+} \mathrm{T}$ cells that produce IL17 represent a distinct lineage (Th17) that produces neither IL-4 nor IFN- $\gamma$. Recently, a relationship between $\mathrm{T}_{\text {reg }}$ cells and Th17 in the pathogenesis of some human autoimmune diseases was reported (Lock C et al 2002, Fujino et al 2003, Vaknin-Dembinsky A et al 2006, Zheng et al 2007).

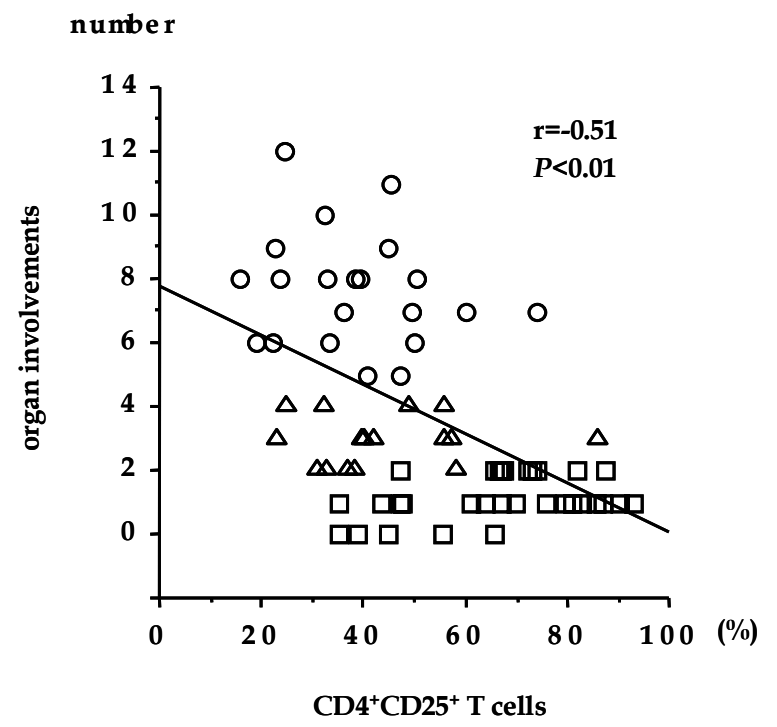

Fig. 7. Correlation between percentage of $\mathrm{CD} 25^{+} \mathrm{CD} 44^{+} \mathrm{T}$ cells and the degree of organ involvement. "Organ involvement" included asthma, sinusitis, pulmonary infiltration, mononeuritis multiplex or polyneuropathy, arthritis, tympanitis, lymphadenitis, mastitis, or involvement of the myocardium, gastrointestinal tract, kidney, skin, central nervous system, eye, gallbladder, or liver. Open circles represent patients with CSS at onset, open triangles represent patients with CSS who relapsed after an initial remission, and open squares represent patients with CSS in remission after treatment. A significant linear relationship is evident $(r=-0.51, P<0.01)$ for all patient groups.

We confirmed that the percentage of CD4+ T cells producing IL-17 was significantly greater in patients with active CSS than in healthy control patients or in patients with asthma, BA + CEP, or inactive CSS (Fig. 8) (Saito et al., 2009). Moreover, the percentage of CD4+ T cells 


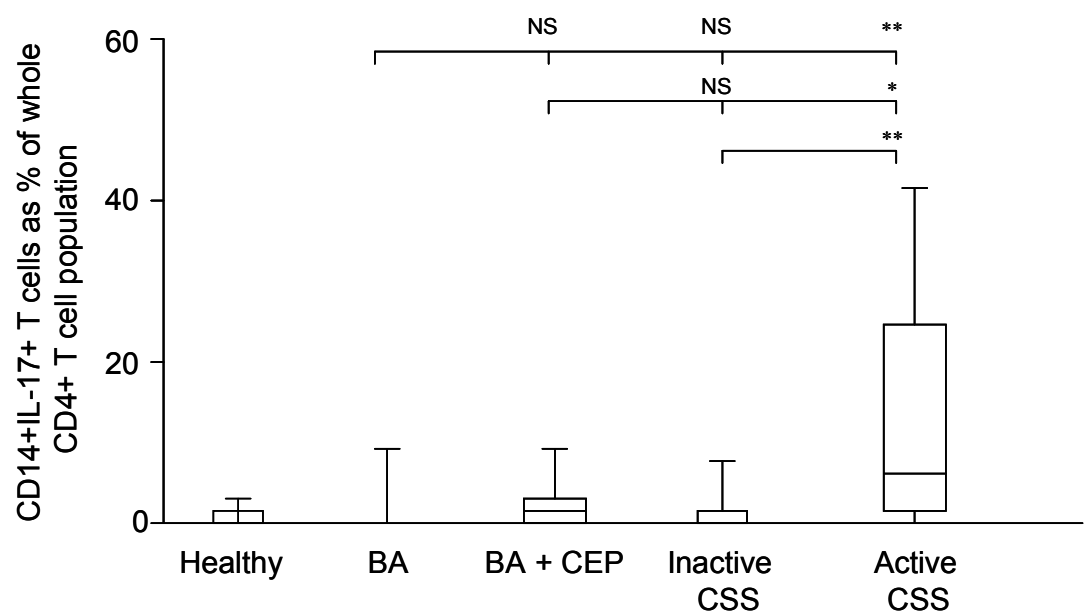

Fig. 8. Increased ability of CD4+ ${ }^{+}$cells from active CSS patients to produce IL-17.

producing IL-17 in active CSS who were at onset or at relapse was significantly greater than those in inactive CSS and the percentage of CD4+CD25+ T cells producing IL-10 (Tr1 cells) in active CSS significantly decreased than those in inactive CSS who achieved remission after treatment ( $\operatorname{Tr} 1)$ (Fig. 9) (Saito et al., 2009). Th17 cells were identified as CD4+ T cells that produced mainly IL-17 and IL-22. Eosinophilia is a characteristic of CSS, and some reports suggest that the IL-25 produced by eosinophils promotes innate adaptive immunity by enhancing Th2 cytokine production (Terrier et al., 2010). We showed that the number of CD4+ T cells producing IL-17 or IL-22 in the peripheral blood of CSS patients increased at
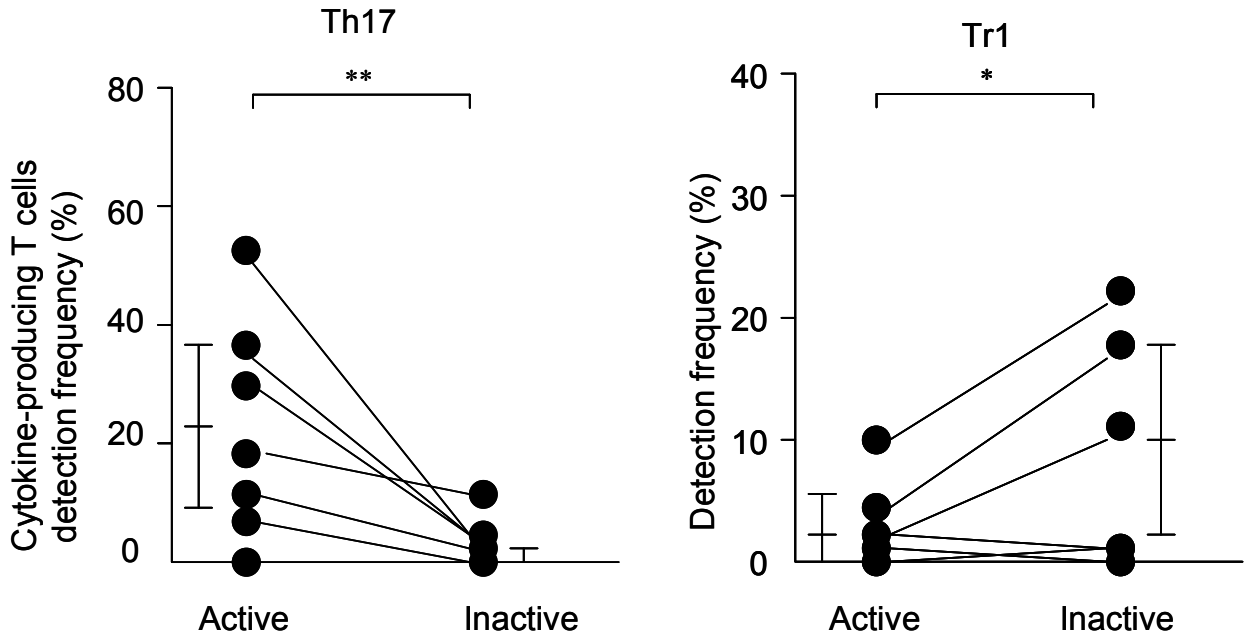

Fig. 9. Th17 or Tr1 cells representing $\mathrm{CD} 4{ }^{+} \mathrm{CD} 25^{+} \mathrm{T}$ cells that produce IL-17 or IL-10 in relation to disease activity in CSS patients. ${ }^{*} P<0.01$, ${ }^{*} P<0.05$. 
relapse and that the numbers of these CD4+ T cells were correlated with the number of CD4+ T cells producing IL-25 (Fig.10) (Saito et al., 2011). Indoleamine 2, 3-dioxygenase (IDO) expression in monocytes from all CSS patients was positively correlated with the percentage of CD4+CD25+ Treg cells producing IL-10 and inversely correlated with the percentage of Th17 cells (Fig. 11) (Saito et al., 2011). Thus CSS relapse may be linked to elevated levels of CD4+ T cells producing IL-25, which promote Th2 inflammation and reduce Tr1 cell subpopulations, which also result from lower IDO expression in monocytes. Thus, the percentages of CD4+CD25+ Treg cells producing IL-10 and of Th17 cells reflect the disease activity of CSS (Fig. 11).

Mononuclear leukocytes derived from patients from each group were stimulated with PMA and ionomycin in the presence of $10 \mu \mathrm{g} / \mathrm{mL}$ of brefeldin A to generate and accumulate IL17. Statistical significance was tested using the Mann-Whitney $U$ test. ${ }^{*}{ }^{*} \mathrm{P}<0.01,{ }^{*} \mathrm{P}<0.05$, NS: not significant.

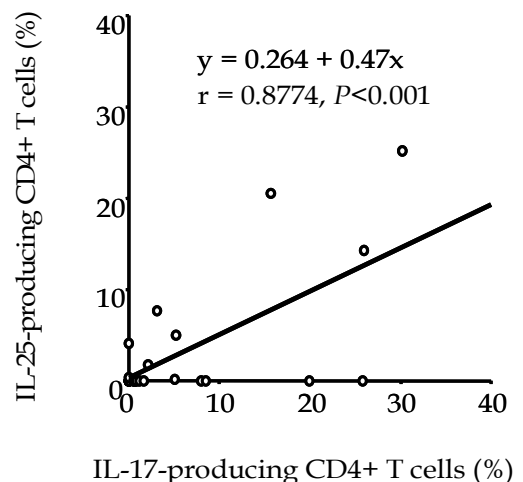

(a)

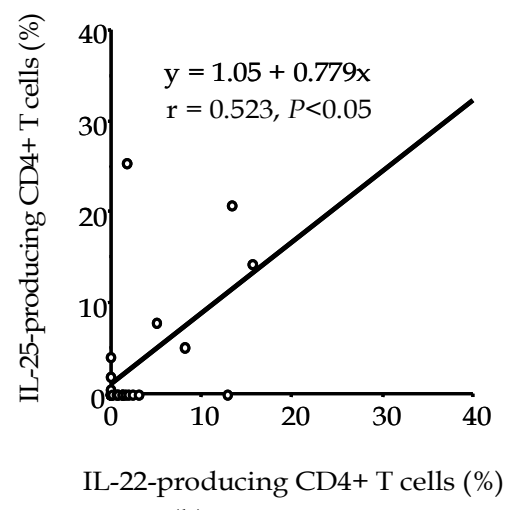

(b)

Fig. 10. Correlation between IL-25 and Th17 cell generation.

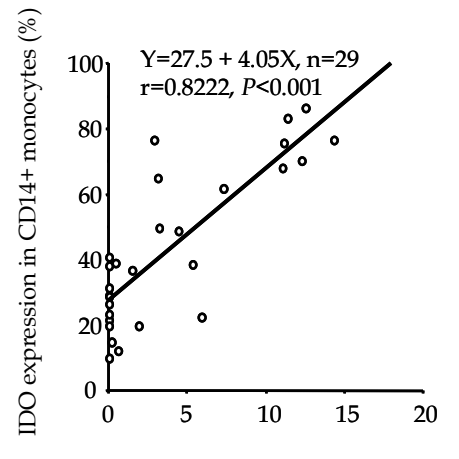

CD4+CD25+ T cells producing IL-10 (\%)

(a)

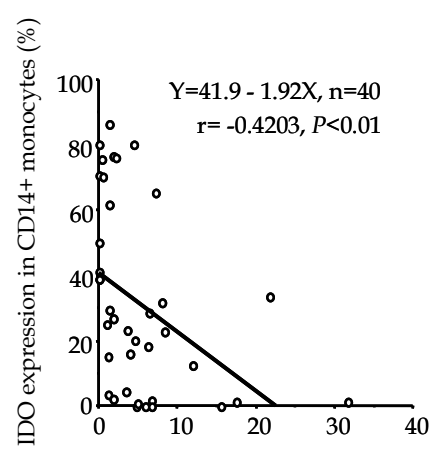

Th17 cells as a proportion of CD4+ T cells (\%)

(b)

Fig. 11. Monocyte IDO expression and CD4 ${ }^{+} \mathrm{CD} 25^{+} \mathrm{T}$ cells that producing IL-10 and Th17 cell detection. 
We found a positive correlation between the percentage of CD4+ $\mathrm{T}$ cells producing IL- 25 and the percentage of CD4+ $\mathrm{T}$ cells producing IL-17 (a) or IL-22 (Fig. 9b) in relapsed CSS patients. The increase in IL-25 may be linked to increased Th17 cell generation.

IDO expression in monocytes from all CSS patients was positively correlated with the detection frequency of $\mathrm{CD} 4{ }^{+} \mathrm{CD} 25^{+} \mathrm{T}$ cells that producing IL-10and inversely correlated with the detection frequency of Th17 cells.

\subsection{Treatment}

The mainstay of treatment for CSS is systemic CS therapy. Additional treatments with immunosuppressive agents, such as CYC or azathioprine, may be used in some patients. Other treatment options include methotrexate, mycophenolate mofetil, rituximab, interferon-alpha, anti-IgE therapy, anti-IL-5 antibodies, anti-TNF-alpha (infliximab, etanercept, adalimumab), plasma exchange, and intravenous immunoglobulin (IVIG). Corticosteroids and immunosuppressants, especially CYC, have improved considerably most symptoms of vasculitis, particularly those involving the gastrointestinal system, skin, and lungs, as well as constitutional symptoms. However mononeuritis multiplex and heart failure in patients with CSS or ANCA-associated systemic vasculitis do not respond to combination therapy with CS and CYC (Abril et al., 2003; Hattori et al., 1999; Renaldini et al., 1993; Sehgal et al., 1995). IVIG therapy has been used to treat various diseases, including MPA, WG, and ANCA-associated systemic vasculitis (Jayne et al., 1991; Lockwood, 1996; Richter et al., 1995). Hamilos and Christensen were the first to report that eosinophilia in CSS is improved by treatment with IVIG (Hamilos \& Christensen, 1991), and other investigators have since described successful treatment with IVIG of CSS itself (Armentia et al., 1993; Levy et al., 1999). We previously reported (Tsurikisawa et al., 2004) that IVIG therapy improved mononeuritis multiplex or heart failure in 14 of 15 patients with CSS who did not respond to combination therapy with CS and CYC. IVIG (400 mg) was given daily for 5 days. Neuropathy was evaluated by assessing manual muscle strength and skin temperature at affected sites. Cardiac function was evaluated by using ejection fraction assessment with echocardiography and two imaging tests of the myocardium (123I-metaiodobenzylguanidine (MIBG) and 201Tl). Peripheral eosinophil counts and CD69 expression on the surfaces of eosinophils were also examined. We found that manual muscle strength improved and the skin temperature of both hands and legs significantly increased on IVIG therapy (Fig. 12). In the five patients with heart failure, the ejection fraction of the left ventricle significantly increased from $35.2 \%$ to $61.0 \%$ (Fig. 13). Myocardial uptake of ${ }^{123}$ MIBG significantly increased, indicating improved myocardial viability (Fig. 14). ${ }^{201} \mathrm{Tl}$ images showed a perfusion defect and, following IVIG therapy, improved blood perfusion. IVIG therapy did not, however, affect the peripheral blood eosinophil count, but it did downregulate the expression of CD69 (Fig. 15). This finding suggests that, in CSS, activated eosinophils survive even after CS or CYC treatment, and that IVIG therapy decreases the number of activated eosinophils that express early activation markers such as CD69. The progression of CSS may, therefore, be related more to the abundance of CD69-expressing eosinophils than to the total number of eosinophils. Thus, one mechanism by which IVIG therapy acts on CSS may be the inactivation of eosinophils. IVIG therapy may induce remission by ameliorating neuropathy and heart failure in those patients who are unresponsive to treatment with CSs or CYC. 


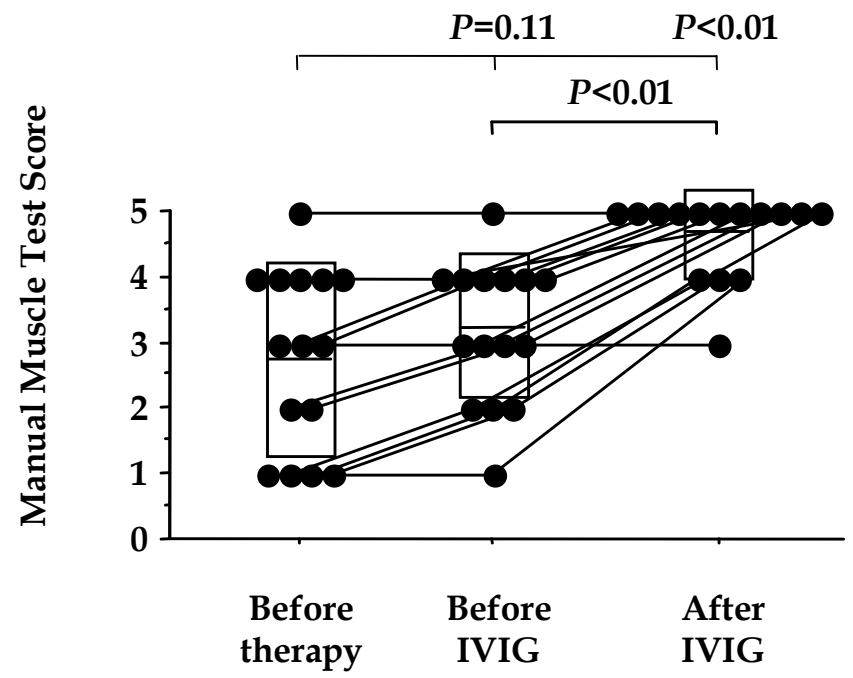

Fig. 12. Manual muscle test. "Before therapy" indicates before treatment with corticosteroid or cyclophosphamide or both; before IVIG and after IVIG indicate before and after highdose intravenous immunoglobulin therapy, respectively.

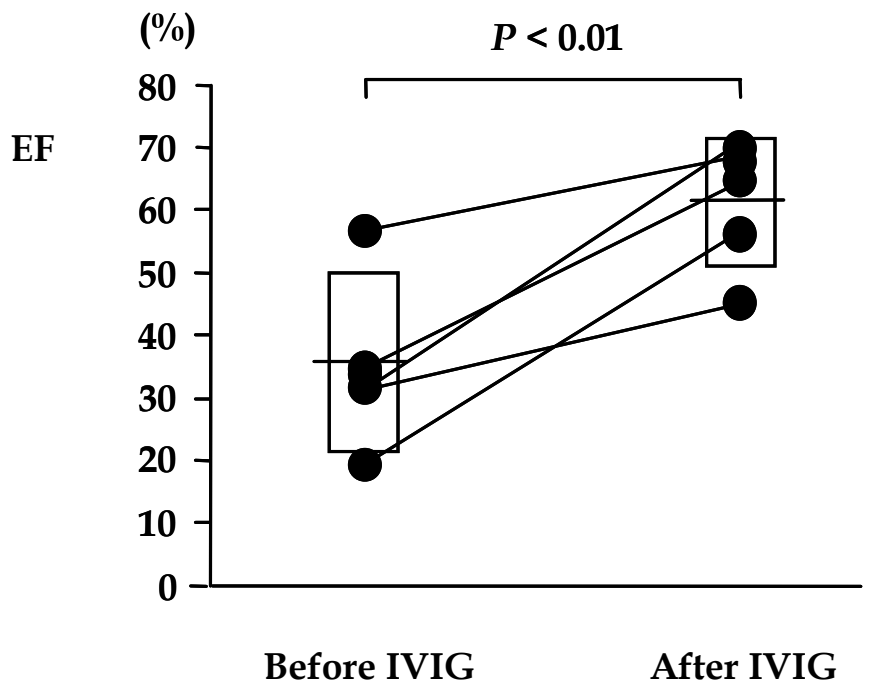

Fig. 13. Ejection fraction as measured by using echocardiography. EF, ejection fraction

Image analysis of MIBG was performed on the regions over the whole left ventricular myocardium and the upper mediastinal area. The heart to mediastinum $(\mathrm{H} / \mathrm{M})$ ratio was then determined from the cardiac ${ }^{123}$ I-MIBG images. The washout rate of MIBG within the myocardium was measured as a percent change in the left ventricular activity from early to delayed images within the left ventricular regions. 
(a) $\mathrm{H} / \mathrm{M}$ ratio

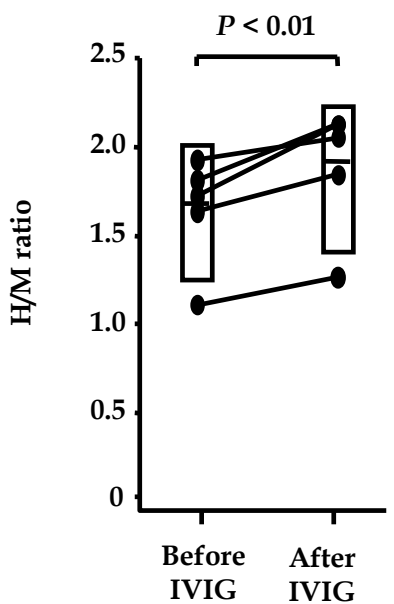

(b) washout rate

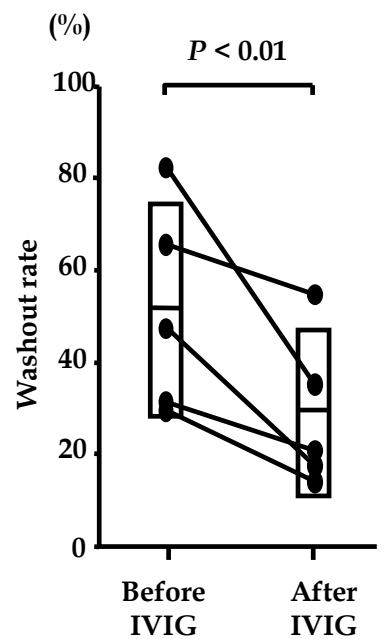

Fig. 14. The heart to mediastinum $(\mathrm{H} / \mathrm{M})$ ratio $(\mathrm{A})$ and washout rate $(\mathrm{B})$ of $123 \mathrm{I}-\mathrm{MIBG}$ in patients with heart failure.

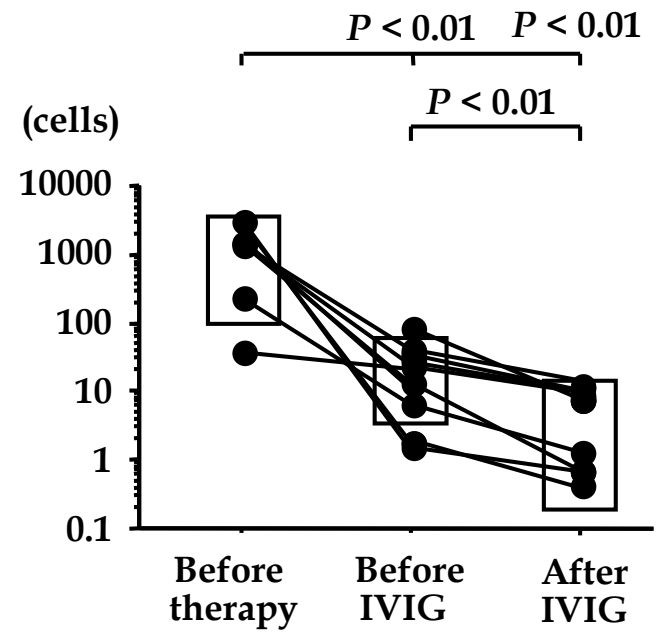

Fig. 15. Effect of intravenous immunoglobulin (IVIG) on $\mathrm{CD} 69^{+}$eosinophil production.

However, administration of IVIG alone, without concomitant treatment with CSs and CYC as an initial treatment approach for CSS, did not improve vasculitic symptoms in various organs, including the digestive tract, skin and pulmonary infiltration. Furthermore, it had no effect on peripheral nerve damage, cardiac dysfunction, the number of eosinophils (including $\mathrm{CD}^{2} 9^{+} \mathrm{CCR} 3^{+}$-activated eosinophils), or the proportion of eosinophils with vacuole formation in white blood cells. This suggests that CS administration reduces 
eosinophil counts but does not reduce the percentage of activated eosinophils, and that IVIG administered with CSs may exhibit an adjuvant effect. IVIG should, therefore, not be used in place of conventional therapy with CSs or immunosuppressants such as CYC, except when patients are resistant to CS and CYC therapy (Guillevin \& Pagnoux, 2003).

After treatment with CSs, immunosuppressants, or IVIG therapy, paralysis-presenting as multiple mononeuropathy-often remains. We consider rehabilitation for multiple mononeuropathy just as important as the therapeutic management of these patients. We found that application of transdermal isosorbide dinitrate (ISDN) patches to the toes of the affected leg or hand produced warming and improved numbness (Fig. 16) (Tsurikisawa et al., 2003). Application of ISDN patches to the affected leg or hand also increased the skin temperature, not only on the affected side but also on the contralateral site. The mechanism involves an increase in blood flow, via local and systemic vasodilating effects, in the region where the ISDN patches are applied; this reduces hyperalgesia and blocks neurogenic inflammation, leading to improved nerve conduction by increasing neuronal postsynaptic cyclic GNP levels.

Peripheral skin temperature

\section{Without ISDN patches}

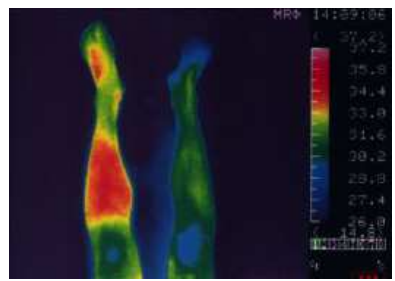

$32.7^{\circ} \mathrm{C}$ $25.7^{\circ} \mathrm{C}$
With ISDN patches on the affected side

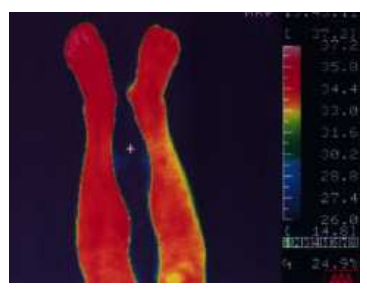

$35.1^{\circ} \mathrm{C} \quad 35.8^{\circ} \mathrm{C}$

Fig. 16. Skin temperature after application of ISDN patches to an affected leg. The skin temperature increased not only in the affected leg, but also on the contralateral side.

\subsection{Prognosis}

Before the use of CSs, the mortality rate of CSS was approximately $50 \%$ within 3 months of diagnosis (Gayraud et al., 2001; Guillevin et al., 1999). Other reports suggest a 5-year survival rate for CSS of $62 \%$ to $80 \%$ (Chumbley et al., 1977; Gayraud et al., 2001; Guillevin et al., 1996; Lane et al., 2005). Most deaths result from complications of the vasculitic phase of the disease and are due to cardiac failure or myocardial infarction, cerebral hemorrhage, renal failure, gastrointestinal bleeding, or status asthmaticus. The presence or absence of the features that make up the five-factor score (FFS) [cardiac involvement, gastrointestinal disease (bleeding, perforation, infarction or pancreatitis), renal insufficiency (creatinine concentration $>1.6 \mathrm{mg} / \mathrm{dl}$; proteinuria $>1 \mathrm{~g} /$ day), and central nervous system involvement] has been used to predict survival in CSS (Gayraud et al., 2001; Guillevin et al., 1996). Of the five elements of the FFS, cardiac involvement and gastrointestinal disease appear to be the strongest indicators of poor prognosis (Guillevin et al., 1999). According to published reports, the remission rate in CSS ranges from $81 \%$ to $91 \%$ and the relapse rate ranges from $20 \%$ to $60 \%$ (Mukhtyar et al., 2008; Pavone et al., 2006. Gastrointestinal involvement, ANCA 
persistent positivity, and a rise in ANCA titer are also risk factors for relapse. We reported that cardiac sympathetic nerve function was damaged in CSS patients with cardiac involvement and that ${ }^{123}$ I-MIBG scintigraphy was useful for detecting cardiac involvement and predicting cardiac events (Horiguchi et al., 2011). 123I-MIBG scintigraphy was performed in 28 patients with CSS, 12 of whom had cardiac involvement, and the early and delayed heart to mediastinum ratio (early $\mathrm{H} / \mathrm{M}$ and delayed $\mathrm{H} / \mathrm{M}$ ) and washout rate were calculated. We found that early $\mathrm{H} / \mathrm{M}$ and delayed $\mathrm{H} / \mathrm{M}$ were significantly lower, and the washout rate was significantly higher, in patients with cardiac involvement than in control patients and those without cardiac involvement (early $\mathrm{H} / \mathrm{M}, P=0.0024, P=0.0001$; delayed $\mathrm{H} / \mathrm{M}, P=0.0002, P=0.0001$; washout rate, $P=0.0012, P=0.0052$; vs. those without cardiac involvement and vs. control patients, respectively). Accuracy in detecting cardiac involvement was $86 \%$ for delayed $\mathrm{H} / \mathrm{M}$ and the washout rate and $79 \%$ for early $\mathrm{H} / \mathrm{M}$ and B-type natriuretic peptide (BNP). Kaplan-Meier analysis showed significantly lower cardiacevent-free rates in patients with early $\mathrm{H} / \mathrm{M} \leq 2.18$ and $\mathrm{BNP}>21.8 \mathrm{pg} / \mathrm{mL}$ than in patients with early $\mathrm{H} / \mathrm{M}>2.18$ and $\mathrm{BNP} \leq 21.8 \mathrm{pg} / \mathrm{mL}$ ( $\log$ rank test $P=0.006)$.

\section{Conclusion}

A prognosis of CSS suggests a 5 -year survival rate in the range of $62 \%$ to $80 \%$, which is far from ideal. CSS involves multilateral systemic vasculitis that shares many clinical characteristics with other ANCA-associated vasculitides, potentially causing a necrotizing process that can involve any organ or system. The clinical features of CSS reflect the pathogenic role of peripheral blood and tissue hypereosinophilia, which can directly contribute to damage of primary organs. These two aspects of the disease complicate diagnosis and the initiation of pharmacologic treatment. The mainstay of treatment for CSS is CSs or CYC or both; however, patients with CSS who experience mononeuritis multiplex or heart failure do not respond to combination therapy with CSs and CYC. We recommended IVIG therapy, in addition to conventional therapy, for CSS patients with severe neuropathy or heart failure who fail to respond to combination therapy with CSs and CYC. IVIG treatment not only decreases the number of activated eosinophils expressing $\mathrm{CD} 9^{+} \mathrm{CCR} 3^{+}$but also could reduce the amount of CS needed for maintenance of remission in CSS (Danieli et al. 2004). Increased availability of novel therapies for CSS, together with a better understanding of the pathogenesis of the disease, should improve the long-term management of this condition.

\section{Acknowledgment}

We thank Drs. Hiroyuki Mitomi, Miyako Ishiyama, Ayako Horita, and Ikuo Saito for their suggestions in the discussion of the pathology of CSS; Drs. Yoriko Horiguchi, Akihiko Ishibashi, Yukiko Morita, and Hideo Himeno for their suggestions in the discussion of cardiac involvement; Dr. Shunsuke Suzuki for his suggestions in the discussion of clinical manifestation; and Dr. Akemi Saito for performing the assays on the serum samples.

\section{References}

Churg, J. \& Strauss, L. (1951). Allergic granulomatosis, allergic angiitis, and periarteritis nodosa. American Journal of Pathology, vol. 27, 277-301 
Jennette, J.C. \& Falk R.J. (1995) Clinical and pathological classification of ANCA associated vasculitis: what are the controversies? Clinical Experimental Immunology, vol. 101: 18-22

Vaglio, A., Martorana D., Maggiore, U., Grasselli, C., Zanetti, A., Pesci, A., Garini, G., Manganelli, P., Bottero, P., Tumiati, B., Sinco, R.A., Savi, M., Buzio, C., \& Neri, T.M. (2007) HLA-DRB4 as a genetic risk factor for Churg-Strauss Syndrome. Arthritis $\mathcal{E}$ Rheumatism vol. 56, 3159-66

Wieczorek S, Hellmich B, Arning L, Moosig F, Lamprecht P, Gross WL \& Epplen JT. (2008) Functionally relevant variations of the interleukin-10 gene associated with antineutrophil cytoplasmic antibody-negative Churg-Strauss Syndrome, but not with Wegener's granulomatosis. Arthritis Rheum 58: 1839-48

Tsurikisawa N, Morita S, Tsuburai T, Oshikata C, Ono E, Saito H, Yanagihara Y \& Akiyama K. (2007) Familial Churg-Strauss Syndrome in Two Sisters.Chest 131:592-4

Gatenby PA, Lucas RM, Engelsen O, Ponsonby AL \& Clements M. (2009) Antineutrophil cytoplasmic antibody-associated vasculitis: could geographic pattern be explained by ambient ultraviolet radiation? Arthritis Rheum 61: 1417-24

Mohammad AJ, Jacobsson LT, Mahr AD Sturfelt G \& Segelmark M. (2007) Prevalence of Wegener's granulomatosis, microscopic polyangiitis, polyarteritis nodosa and Churg-Strauss Syndrome within a defined population in southern Sweden. Rheumatology (Oxford) 46: 1329-37

Mahr A, Guillevin L, Poissonnet M \& Ayme S. (2004) Prevalence of polyarteritis nodosa, microscopic polyangiitis, Wegener's granulomatosis, and Churg-Strauss Syndrome in a French urban multiethnic population in 2000: a capture-recapture estimate. Arthritis Rheum 51: 92-9

Sinico RA \& Bottero P. (2009) Churg-Strauss angiitis. Best Pract Res Clin Rheumatol 23: 35566

Kahn JE, Bletry O \& Guillevin L. (2008) Hypereosinophilic syndromes. Best Pract Res Clin Rheumatol 22: 863-82

Lanham J, Elkon K, Pusey C, Hughes G. (1984) Systemic vasculitis with asthma and eosinophilia: A clinical approach to the Churg-Strauss syndrome. Medicine 63: 6581

Mukhtyar C, Flossmann O, Hellmich B, Bacon P, Cid M, Cohen-Tervaert JW, Gross WL, Guillevin L, Jayne D, Mahr A, Merkel PA, Raspe H, Scott D, Witter J, Yazici H \& Luqmani RA. (2008) European Vasculitis Study Group (EUVAS). Outcomes from studies of antineutrophil cytoplasm antibody associated vasculitis: a systemic review by the European League Against Rheumatism systemic vasculitis task force. Ann Rheum Dis 67: 1004-10

Guillevin L \& Pagnoux C. (2003) When should immunosuppressants be prescribed to treat systemic vasculitides? Internal Med 42: 313-317

Pagnoux C \& Guillevin L. (2010) Churg-Strauss Syndrome: evidence for disease subtypes? Curr Opin Rheumatol 22:429-43

Keogh KA \& Specks U. (2003) Churg-Strauss Syndrome: clinical presentation, antineutrophil cytoplasmic antibodies, and leukotriene receptor antagonists. Am J Med 115: 632-8

Kallenberg CG. (2005) Churg-Strauss Syndrome: just one disease entity? Arthritis Rheum 52: 2589-93

Guillevin L, Cohen P, Gayraud M, Lhote F, Jarrousse B \& Casassus P. (1999) Churg-Strauss syndrome. Clinical study and long-term follow-up of 96 patients. Medicine. 78: 2637 
Chumbley LC, Harrison EG \& DeRemee RA. (1977) Allergic granulomatosis and angiitis (Churg-Strauss syndrome). Mayo Clin Proc 52: 477-84

Tsurikisawa N, Tsuburai T, Saito H, Morita S, Horiguchi Y, Mitomi H \& Akiyama K. (2007) A retrospective study of bronchial hyperresponsiveness in asthmatic patients prior to the onset of Churg-Strauss Syndrome. Allergy Asthma Proc 28:336-43

Steinfeld S, Golstein M \& De Vuyst P. (1994) Chronic eosinophilic pneumonia (CEP) as a presenting feature of Churg-Strauss syndrome (CSS). Eur Respir J 7: 2098

Lhote F \& Guillevin L. (1995) Polyarteritis nodosa, microscopic polyangiitis, and ChurgStrauss syndrome. Clinical aspects and treatment. Rheum Dis Clin North Am 21:911-47

Marchand E \& Cordier JF. (2006) Idiopathic chronic eosinophilic pneumonia. Semin Respir Crit Care Med 27:134-41.

Cottin V \& Cordier JF. (2005) Eosinophilic pneumonias. Allergy 60:841-57

Albera C, Ghio P, Solidoro P, Mabritto I, Marchetti L \& Pozzi E. (1995) Activated and memory alveolar T-lymphocytes in idiopathic eosinophilic pneumonia. Eur Respir J 8:1281-5

Sakaguchi S. (2000) Regulatory T cells: key controllers of immunologic self-tolerance. Cell 101:455-8.

Jonuleit H, Schmitt E, Kakirman H, Stassen M, Knop J \& Enk AH. (2002) Infectious tolerance: human $\mathrm{CD} 25(+)$ regulatory $\mathrm{T}$ cells convey suppressor activity to conventional CD4(+) T helper cells. J Exp Med 196:255-60.

Weiner HL. (2001) Induction and mechanism of action of transforming growth factor-betasecreting Th3 regulatory cells. Immunol Rev 182:207-14.

Roncarolo MG \& Battaglia M. (2007) Regulatory T-cell immunotherapy for tolerance to self antigens and alloantigens in humans. Nat Rev Immunol 7:585-98.

Tsurikisawa N, Saito H, Tsuburai T, Oshikata C, Ono E, Mitomi H \& Akiyama K. (2008) Differences in regulatory $\mathrm{T}$ cells between Churg-Strauss syndrome and chronic eosinophilic pneumonia with asthma. J Allergy Clin Immunol 122:610-6

Saito H, Tsurikisawa N, Tsuburai T \& Akiyama K. (2008) Involvement of regulatory T cells in the pathogenesis of Churg-Strauss syndrome. Int Arch Allergy Immunol 146: 736

Lock C, Hermans G, Pedotti R, Brendolan A, Schadt E, Garren H, Langer-Gould A, Strober S, Cannella B, Allard J, Klonowski P, Austin A, Lad N, Kaminski N, Galli SJ, Oksenberg JR, Raine CS, Heller R, Steinman L. (2002) Gene-microarray analysis of multiple sclerosis lesions yields new targets validated in autoimmune encephalomyelitis. Nat Med 8: 500-508

Fujino S, Andoh A, Bamba S, Ogawa A, Hata K, Araki Y, Bamba T, Fujiyama Y. (2003) Increased expression of interleukin 17 in inflammatory bowel disease. Gut Jan;52(1):65-70.

Vaknin-Dembinsky A, Balashov K, Weiner HL. (2006) IL-23 is increased in dendritic cells in multiple sclerosis and down-regulation of IL-23 by antisense oligos increases dendritic cell IL-10 production. J Immunol Jun 15;176(12):7768-74.

Zheng Y, Valdez PA, Danilenko DM, Hu Y, Sa SM, Gong Q, Abbas AR, Modrusan Z, Ghilardi N, de Sauvage FJ, Ouyang W. (2008) Interleukin-22 mediates early host defense against attaching and effacing bacterial pathogens.Nat Med. Mar;14(3):282-9.

Saito H, Tsurikisawa N, Tsuburai T, Oshikata C \& Akiyama K. (2009) Cytokine production profile of CD4+ T cells from patients with active Churg-Strauss syndrome tends toward Th17. Int Arch Allergy Immunol. 149 Suppl 1:61-5. 
Terrier B, Bièche I, Maisonobe T, Laurendeau I, Rosenzwajg M, Kahn JE, Diemert MC, Musset L, Vidaud M, Sène D, Costedoat-Chalumeau N, Le Thi-Huong D, Amoura Z, Klatzmann D, Cacoub P, Saadoun D. (2010) Interleukin-25: a cytokine linking eosinophils and adaptive immunity in Churg-Strauss syndrome. Blood. Nov 25;116(22):4523-31.

Saito H, Tsurikisawa N, Tsuburai T, Oshikata C \& Akiyama K. (2011) The proportion of regulatory $\mathrm{T}$ cells in the peripheral blood reflects the relapse or remission status of patients with Churg-Strauss syndrome. Int Arch Allergy Immunol 155 Suppl; 46-52

Abril A, Calamia KT \& Cohen MD. (2003) The Churg Strauss syndrome (allergic granulomatous angiitis): review and update. Semin Arthritis Rheum 33: 106-14

Hattori N, Ichimura M, Nagamatsu M, Li M, Yamamoto K, Kumazawa K, Mitsuma T \& Sobue G. (1999) Clinicopathological features of Churg-Strauss syndrome-associated neuropathy. Brain 122, 427-39

Sehgal M, Swanson JW, DeRemee RA \& Colby TV. (1995) Neurological manifestations of Churg-Strauss syndrome. Mayo Clin Proc. 70: 337-341

Renaldini E, Spandrio S, Cerudelli A, Affatato A \& Balestrieri GP. (1993) Cardiac involvement in Churg-Strauss syndrome: a follow-up of three cases. Eur Heart J. 14: $1712-1716$

Hamilos D.L \& Christensen J. (1991) Treatment of Churg-Strauss syndrome with high-dose intravenous immunoglobulin. J. Allergy Clin Immunol. 88: 823-4

Tsurikisawa N, Taniguchi M, Saito H, Himeno H, Ishibashi A, Suzuki S \& Akiyama K. (2004) Treatment of Churg-Strauss syndrome with high-dose intravenous immunoglobulin. Annals Allergy Asthma Immunol, 92: 80-7

Tsurikisawa N, Taniguchi M, Suzuki S \& Akiyama K. (2003) Effects of a nitro compound patch on neuropathy in Churg-Strauss syndrome. Allergy 58:686-7

Gayraud M, Guillevin L, Toumelin P, Cohen P, Lhote F, Casassus P \& Jarrousse B. (2001) Long-term followup of polyarteritis nodosa, microscopic polyangiitis, and ChurgStrauss syndrome. Arthritis Rheumatism. 44: 666-75

Guillevin L, Lhote F, Gayraud M, Cohen P, Jarrousse B, Lortholary O, Thibult N \& Casassus P. (1996) Prognostic factors in polyarteritis nodosa and Churg-Strauss syndrome: a prospective study in 342 patients. Medicine (Baltimore) 75: 17-28

Lane SE, Watts RA, Shepstone L \& Scott DGI. (2005) Primary systemic vasculitis: clinical features and mortality. Q J Med 98:97-111

Pavone L, Grasselli C, Chierici E, Maggiore U, Garini G, Ronda N, Manganelli P, Pesci A, Rioda WT, Tumiati B, Pavesi G, Vaglio A \& Buzio C. (2006) Outcome and prognostic factors during the course of primary small-vessel vasculitides. J. Rheumatology 33: 1299-306

Horiguchi Y, Morita Y, Tsurikisawa N \& Akiyama K. (2011) 123I-MIBG imaging detects cardiac involvement and predicts cardiac events in Churg-Strauss syndrome. Eur J Nucl Med Mol Imaging 38: 221-9

Sinco RA, Di Toma L, Maggiore U, Bottero P, Radice A, Tosoni C, Gregorini G, Monti S, Frassi M, Vecchio F, Corace C, Venegoni E \& Buzio C. (2005) Prevalence and clinical significance of antineutrophil cytoplasmic antibodies in Churg-Strauss syndrome. Arthritis Rheum 52: 2926-35

Danieli MG, Cappelli M, Malcangi G, Logullo F, Salvi A, Danieli G. (2004) Long term effectiveness of intravenous immunoglobulin in Churg-Strauss syndrome. Ann Rheum Dis 63: 1649-54 


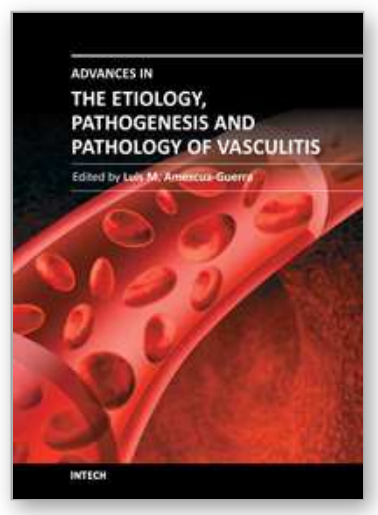

\author{
Advances in the Etiology, Pathogenesis and Pathology of \\ Vasculitis \\ Edited by Dr. Luis M Amezcua-Guerra
}

ISBN 978-953-307-651-5

Hard cover, 438 pages

Publisher InTech

Published online 17, October, 2011

Published in print edition October, 2011

This book represents the culmination of the efforts of a group of outstanding experts in vasculitis from all over the world, who have endeavored to devote their work to this book by keeping both the text and the accompanying figures and tables lucid and memorable. Here, you will find an amalgam between evidencebased medicine to one based on eminence, through an exciting combination of original contributions, structured reviews, overviews, state-of the-art articles, and even the proposal of novel pathogenetic models of disease. The book contains contributions on the etiology and pathology of vasculitis, the potential role of endothelial cells and cytokines in vascular damage and repair as well as summaries of the latest information on several primary and secondary vasculitis syndromes. It also covers selected topics such as organ-specific vasculitic involvement and quality of life issues in vasculitis. The editor and each of the authors invite you to share this journey through one of the most exciting fields of the medicine, the world of Vasculitis.

\title{
How to reference
}

In order to correctly reference this scholarly work, feel free to copy and paste the following:

Tsurikisawa N., Saito H., Oshikata C., Tsuburai T. and Akiyama K. (2011). The Etiology, Mechanisms, and Treatment of Churg-Strauss Syndrome, Advances in the Etiology, Pathogenesis and Pathology of Vasculitis, Dr. Luis M Amezcua-Guerra (Ed.), ISBN: 978-953-307-651-5, InTech, Available from:

http://www.intechopen.com/books/advances-in-the-etiology-pathogenesis-and-pathology-of-vasculitis/theetiology-mechanisms-and-treatment-of-churg-strauss-syndrome

\section{INTECH}

open science | open minds

\section{InTech Europe}

University Campus STeP Ri

Slavka Krautzeka 83/A

51000 Rijeka, Croatia

Phone: +385 (51) 770447

Fax: +385 (51) 686166

www.intechopen.com

\section{InTech China}

Unit 405, Office Block, Hotel Equatorial Shanghai

No.65, Yan An Road (West), Shanghai, 200040, China

中国上海市延安西路65号上海国际贵都大饭店办公楼405单元

Phone: +86-21-62489820

Fax: $+86-21-62489821$ 
(C) 2011 The Author(s). Licensee IntechOpen. This is an open access article distributed under the terms of the Creative Commons Attribution 3.0 License, which permits unrestricted use, distribution, and reproduction in any medium, provided the original work is properly cited. 